word is due to the fact that the record is of a lady's voice.

The above short account of the phonetic kymograph will give some idea of the scope of the apparatus. It will be seen that the instrument is

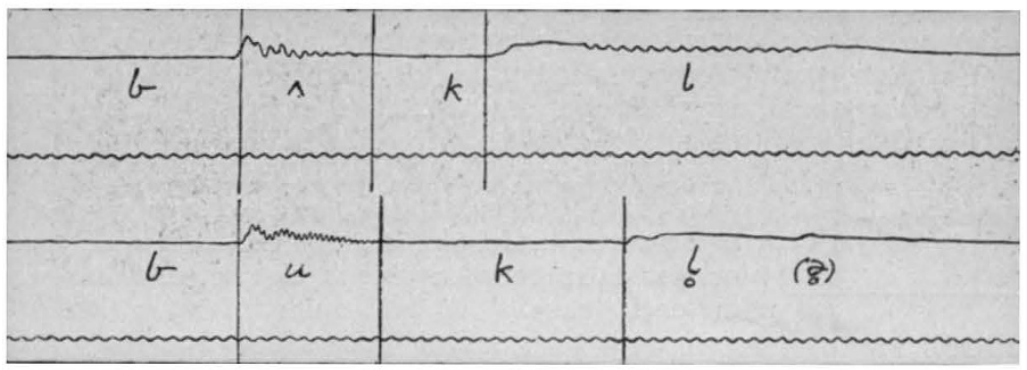

FiG. 8.-A, mouth-tracing of English buckle (male voice); R, mouth-tracing of French boucle (female voice).

chiefly useful (I) for detecting the presence or absence of voice, (2) for detecting the presence or absence of nasality, (3) for measuring the lengths of sounds, and (4) for calculating the pitch of the voice. DANIEL JONES.

\section{A UNIVERSITY DEGREE IN} HORTICULTURE.

THE University of London has, at the suggestion of the council of the Royal Horticultural Society, established a B.Sc. degree in Horticulture. Syllabuses for internal and external students have been drafted, and the University has under consideration the recognition of the Royal Horticultural Society's school and research station at Wisley as a school of the University.

There can be no question that, if university degrees are to be given in technical subjects, the case for a degree in horticulture is a good one; for horticulture connotes not only an industry and an art, but also an applied science.

First of all, however, it is a craft, and, like all crafts, it depends for its successful pursuit on the exercise of practical skill. Therefore, an academic recognition of proficiency which does not carry with it a sure indication of craftsmanship is not only useless, but also pernicious.

The proposed degree in horticulture, if the spirit of the regulations which govern it is observed, makes adequate provision for the requirement of technical expertness. A candidate for the internal degree, besides matriculating and passing the Intermediate Science Examination, must pass the Preliminary Examination for the National Diploma in Horticulture before he proceeds to the Final Examination. This examination, established by the Royal Horticultural Society with the approval of the Board of Agriculture, is an adequate elementary test of practical knowledge and ability. Furthermore, during the final course candidates are required to perfect their knowledge of practical horticulture, NO. 2484, VOL. 99] and the sciences which are prescribed in the course of study are to be taught with definite reference to horticulture.

If, therefore, a student follows this course at a horticultural college, there is but little danger that general science, botany and chemistry and entomology, will divert unduly the student's interest from horticulture. The Bachelor of Science in Horticulture would thus be possessed of a fair knowledge of science, and would also be a proficient practical horticulturist, able to dig and trench, plant and prune, bud and graft at best as well as the average gardener. If this prove, in fact, to be the case, both science and horticulture will gain. For at present there is a deep gulf fixed between the science and practice of horticulture. The well-trained man of science, say the Part II. Tripos man, has become too specialised in habits of work, too much a victim of the laboratory habit, to be willing to spend a year or so working with his hands on the land.

For these reasons it may be hoped that the establishment of a degree in horticulture will be of no less benefit to potential botanists and agricultural chemists than to professional horticulturists. In the case of botany, at all events, it may reasonably be asserted that much of the botanical ritual observed in our university laboratories is outworn; and although we are not confusing botanists with gardeners, we are confident that, if botanical students were to spend half as many hours working in the garden as they now spend with microscopes and microtomes, they would become better botanists.

From yet another point of view the degree in horticulture is to be welcomed. Tropical horticulture is in many cases more akin to horticulture than to the agriculture practised in this country. The Empire has great need of men to aid in developing its resources. The oId class of administrator-the man who could administer anything about which he knew nothing-has been found out. The war has weighed him in the balances and proved him wanting. The new class of administrator must be a new kind of practical man-“"a hewer, not a heaver, of things." By providing a course of training in the practice and science of horticulture, the University of London has made a contribution towards meeting the need for this new class of practical men.

This will only be the case, however, if the University insists upon satisfactory practical training for all candidates for degrees in horticulture, and not from internal students only. Unfortunately, the regulations for the external degree in horticulture provide for no training in practical horticulture, nor, to be fair, does it 
provide for training in anything else. This omission can satisfy only those who believe that ability to pass an examination is sufficient evidence of training. External students are required to pass an examination in practical horticulture. The test lasts one day only, whereas not fewer than two days, and preferably three, should be spent by the student in demonstrating his skill in practical horticulture. Unless the examination is so arranged as to secure that every recipient of the degree has a sound knowledge of practical horticulture, the establishment of a degree in this subject will do more harm than good.

\section{CONTINUATIVE EDUCATION IN FRANCE.}

F NGLAND is not the only Allied country that is thinking of putting its educational house in order, even before the end of the war. Our good neighbour France is engaged on a similar project. Thanks to the kindness of M. Maurice Roger, one of the leading specialists on technical education in France, the present writer is able to give a brief account of the French proposals, which, in the light of Mr. Fisher's somewhat tantalising treatment of the subject, cannot fail greatly to interest the English public.

The Bill before the French Chamber is essentially a consolidating measure, while at the same time it introduces the principle of compulsion, the attempt at voluntary continuative education having failed to produce adequate results. Hitherto commercial and technical education have formed the subject of one law, agricultural of another, and physical training of a third. All three laws have passed one or other of the two Chambers. The new proposals will co-ordinate the three laws in one in order that the education of the future student may be similarly coordinated.

The aim of the education will be alike economic and civic, and the physical education will, in the case of the male student, lead up to military training. The unskilled, as well as the skilled, employee must attend these schools, which are not to be schools for workmen, but schools where workmen, especially the unskilled, may increase their economic productivity. It is significant to note that, in spite of the centralising traditions of French education, the classes are to be organised in accordance with local or regional needs, under the guidance of local committees for each commune. When the commune is a large town like Paris or Marseilles, the unit chosen seems very suitable, but in the case of the small village it is certainly not large enough. Such committees are to be composed of town and district councillors, doctors, official members, representatives of chambers of commerce and agricultural societies (very strong and influential bodies in certain parts of France), and delegates from associations of employers and trade-unions and various other important local societies. Above them will be a county council committee, and at the top a central committee to exercise a general oversight and control. Two stages of study are mapped out; the first is up to seventeen for boys and sixteen for girls.

Curiously enough, the recent English Departmental Committee on Juvenile Education in relation to Employment after the War also recommended two stages, but the first in the English proposals extends only to sixteen years of age. In this first period in the French scheme the obligatory subjects are French, history and geography, physical exercises, science applied to agriculture, industry, commerce, and navigation, or domestic economy, comprising practical work in each case. A minimum of fifty hours is assigned to general education, $\mathrm{I}_{50}$ to professional, and roo to physical, the last being allotted to Sunday. This makes 300 hours, as against 320 suggested by the English committee, which proposes a minimum of only about fifty hours a week for physical exercises.

The second stage is from seventeen to twenty years of age for young men and sixteen to eighteen for girls, compared with sixteen to eighteen for English students. French, conferences on history, geography, civics, common law, and political economy, are assigned a minimum of roo hours, and the same amount is to be devoted to gymnastics and the preparation for military service. For girls the place of the latter is taken by manual work, hygiene, and some notions of medicine and child-rearing.

Existing technical, commercial, and higher elementary school buildings are to be utilised so far as possible for giving continuative education. The more technical subjects will be taught by professional teachers, but elementary-school teachers will be largely used for the more general parts of the course. To enable them to give the extra time out of school, the ordinary day-school hours will be shortened by half an hour, and the summer holidays increased to two months. If more than 200 teaching hours of continuative education are required of them they are to receive extra pay. It is very significant to note that private schools will be allowed, under certain conditions, to provide continuative education.

\section{Cloudesley Brereton.}

\section{NOTES}

THE list of honours conferred on the occasion of the celebration of the King's birthday on June 3 includes the following names of men known in scientific circles:-Baronets: Sir Thomas Elliott, Deputy-Master and Comptroller of the Mint (retiring); Sir Robert Hadfield, F.R.S., past-president of the Iron and Steel Institute and of the Faraday Society; Mr. James Knott, formerly president of the Institute of Marine Engineers; Sir Philip Magnus, representative in Parliament for the University of London since 1906; the Right Hon. T. W. Russell, Vice-President of the Department of Agriculture and Technical Instruction for Ireland; Dr. Frederick Taylor, president of the Royal College of Physicians. Knights: Prof. W. J. Ashley, professor and dean of the faculty of commerce at BirmingNO. 2484, VOL. 99] 